\title{
Nutritional Status in Patients with Chronic Pancreatitis
}

\author{
Yuriy A. Kucheryavyy ${ }^{*}$ and Dmitry N. Andreev
}

\begin{abstract}
Department of Internal Diseases Propaedeutics and Gastroenterology, Moscow State University of Medicine and Dentistry Named After A.I. Evdokimov of the Ministry of Healthcare of the Russian Federation, Delegatskaya Street, 20/1, 127473 Moscow, Russia
\end{abstract}

\begin{abstract}
Chronic pancreatitis (CP) is defined as a continuing inflammatory disease of the pancreas that is characterized by irreversible morphological changes often associated with pain and the loss of exocrine and/or endocrine function, which may be clinically relevant. Maldigestion (absolute deficiency of pancreatic enzyme secretion) is a typical complication of CP of any etiology with long anamnesis. Fat malabsorption is considered to be the malnutrition base in CP patients. The purpose of this article is to evaluate the role of nutritive status and nutritive deficiency in CP patients, evaluate diagnostic approaches, correct nutritive status deviation with reference to previous experience, and explore the present situation and possible future perspectives.
\end{abstract}

Keywords: Chronic pancreatitis, exocrine pancreatic insufficiency, maldigestion, malnutrition, nutritive status.

\section{INTRODUCTION}

Chronic pancreatitis (CP) is defined as a continuing inflammatory disease of the pancreas characterized by irreversible morphological changes often associated with pain and the loss of exocrine and/or endocrine function, which may be clinically relevant [1]. The annual incidence of CP ranges from 5 to $12 / 100,000$ individuals; the prevalence of $\mathrm{CP}$ is approximately $50 / 100,000$ persons in the US [2]. The condition is most often caused by alcohol abuse over many years. Repeated episodes of acute pancreatitis can lead to chronic pancreatitis. Heredity may be a contributing factor in some cases, and sometimes the cause is not known.

Maldigestion (absolute deficiency of pancreatic enzyme secretion) is a typical complication of CP or acute necrotizing pancreatitis and can be a conesquence of pancreatic resection or pancreatectomy in $\mathrm{CP}$ patients [3]. Exocrine pancreatic insufficiency (EPI) in CP patients leads to steatorrhea, body weight loss, malnutrition [4], and consequently a major reduction in quality of life [5].

The average time between the onset of the first symptoms of $\mathrm{CP}$ and the appearance of signs of maldigestion is 8-9 years in patients with alcoholic CP and over 15 years in patients with idiopathic nonalcoholic pancreatitis [6]. At present, many CP patients suffer from chronic pancreatic pain that often requires treatment with narcotic analgesics $[7,8]$. However, pain relief therapies are often not efficient and surgery is

*Address correspondence to this author at the Department of Internal Diseases Propaedeutics and Gastroenterology, Moscow State University of Medicine and Dentistry Named After A.I. Evdokimov of the Ministry of Healthcare of the Russian Federation, Delegatskaya Street, 20/1, 127473 Moscow, Russia;

Tel: +7-495-6812229; Fax: +7-495-6096700; E-mail: proped@mail.ru indicated (resection or complex methods with longitudinal pancreaticojejunostomy or total pancreatectomy with autotransplantation of pancreatic islet cells) [7], resulting in an additional increase in maldigestion.

The acute structural damage of the pancreas added to a deep functional insufficiency of this vitally important organ has a tremendous impact on the patient's metabolism: nutrients are not digested normally, leading to a progressive insufficiency of macronutrients and micronutrients; such damage is often associated with diabetes. Despite the attention paid by physicians to the probable nutritional insufficiency in CP patients, malnutrition develops frequently in clinical practice [9].

The underestimation of the nutrient deficiency and nutritive insufficiency in $\mathrm{CP}$ could be partly explained by the rather complicated malnutrition pathophysiology of the disease, including various limitations in nutrition other than maldigestion and diabetes. In particular, the postprandial strengthening of pain, specificity of the food ration associated with chronic alcoholism $[6,10]$, and other pathophysiological aspects will be detailed in this article.

The purpose of this article is to evaluate the role of nutritive status and insufficiency in CP patients, to evaluate diagnostic approaches and to correct deviations in nutritive status in light of previous experience, current practice, and possible future perspectives.

\section{NUTRITIVE STATUS AND CHRONIC PANCREATITIS}

\section{History of Studies}

The aspects of nutritive status evaluation and characteristics of nutrition in $\mathrm{CP}$ patients were 
thoroughly examined in special planned studies performed in the 1980s [11,12] up to recent publications $[13,14,15]$. Objectively, few studies have estimated nutritive status in CP patients; however, the number of publications has definitely increased. Many studies have evaluated only a few markers $[11,16,17]$ or a small combination of parameters [12,14,15,18-24]: the deficiency of fat- or water-soluble vitamins, microelements, protein transport in the blood, lipids, clinical blood analysis parameters and a few others. In some studies, malnutrition or its complications have been evaluated in combination with nutritional parameters [12-14,19,25,26], and others have assessed the efficacy of substitutive enzyme therapy on the dynamics of nutritional parameters in CP patients $[12,13,27]$. The main studies evaluating nutritive status in CP patients are presented in Table 1.

\section{The Pathophysiology of Nutritive Insufficiency in CP}

Fat malabsorption is considered to be the malnutrition base in CP patients [28]. The severity of malnutrition in $\mathrm{CP}$ patients correlates with three main pathogenetic factors $[4,6]$ :

- Initial nutrient deficiency, which is caused by alcohol addiction and is revealed clinically by strong postprandial pain or other factors that limit food rations;

- Pancreatic maldigestion and secondary malabsorption syndrome (loss of nutrients);

- $\quad$ Hypermetabolism, the inflammation process that occurs in the pancreas and defines the severity of the disease (excessive calorie consumption).

It is well known that CP patients often restrict their food rations because of postprandial pain. As a result of the smaller rations of food and dietary fibers, steatorrhea and diarrhea increase [6]. A low BMI $(<20$ $\mathrm{kg} / \mathrm{m}^{2}$ ), diarrhea and steatorrhea occur in $32 \%, 57 \%$ and $24 \%$ of CP patients, respectively, and these patients need medical rehabilitation [29]. Other studies have demonstrated a nutritive deficiency in CP patients who require surgery; this deficiency persists for an extended period during the postoperative period [3032]. A recent study demonstrated a reduction of thin body mass with fat layer retention in alcoholic CP patients and a deficiency of magnesium and vitamin $D$ with lower cholesterol levels in persons without pancreatitis who are addicted to alcohol [24].

Maldigestion develops after pancreatic parenchymal injury and progressive fibrosis, leading to a deficiency of bicarbonate secretion in patients with CP. Maldigestion restricts the patient to a vicious circle of pathogenesis in which the patient cannot digest and assimilate sufficient and balanced food rations in the absence of substitutive enzyme therapy [33].

Hypermetabolism in CP patients develops concurrently with the inflammation process in the pancreas. Attacks of pancreatitis are accompanied by a metabolic reaction, which is rather difficult to differentiate from acute pancreatitis [34] or sepsis [35, 36]. The resting energy expenditure in $\mathrm{CP}$ patients is $30-50 \%$ higher than normal [37] and confirms the hypermetabolism status in CP patients [38]. The proteolysis of skeletal muscles in hypermetabolism is accompanied by a decrease of $40 \%$ in amino acid levels and a loss of $15 \%$ of the total volume of muscle mass [10]. This persistent negative nitrogen balance has an important impact on the survival of patients who suffer from acute pancreatitis [39]. Patients with CP often undergo catabolic stress and have increased levels of catecholamines and cortisol as well as an abnormal insulin/glucagon secretion balance that results from beta cell dysfunction, leading to the development of insulin resistance [10,40]. Fat metabolism in CP patients can also change with respect to lipolysis activation and acceleration of lipid peroxyl oxidation processes [34,41] when lipid clearance decreases as a result of hypercholesteremia and hypertriglyceridemia $[10,34,42]$.

Hypermetabolism in CP can cause gradual exhaustion of the nutrient reserves, and persistent symptomatology (pain, nausea and vomiting, gastrostasis, and continued alcohol intake) will cause nutrition abnormalities and intensify deficiencies in macronutrients and micronutrients [33, 43].

In addition, other mechanisms may participate in the development of malnutrition in CP patients, but the role of such mechanisms is less well supported. Glycosuria, as a cause of nutrient loss and secondary nutrition limitation as well as the accompanying gastrointestinal diseases, may be additional causes of nutrient loss or insufficient nutrient supplies. Patients with alcohol addiction typically have hypokinesis, a physical inertness that will be the background for progressive muscle hypotrophy [29].

\section{Nutritive Deficiency and Clinical Course of CP}

Malnutrition in CP patients is not only a complication of the disease but also influences its course. CP 
Table 1: Clinical Studies of the Nutritive Status of CP Patients

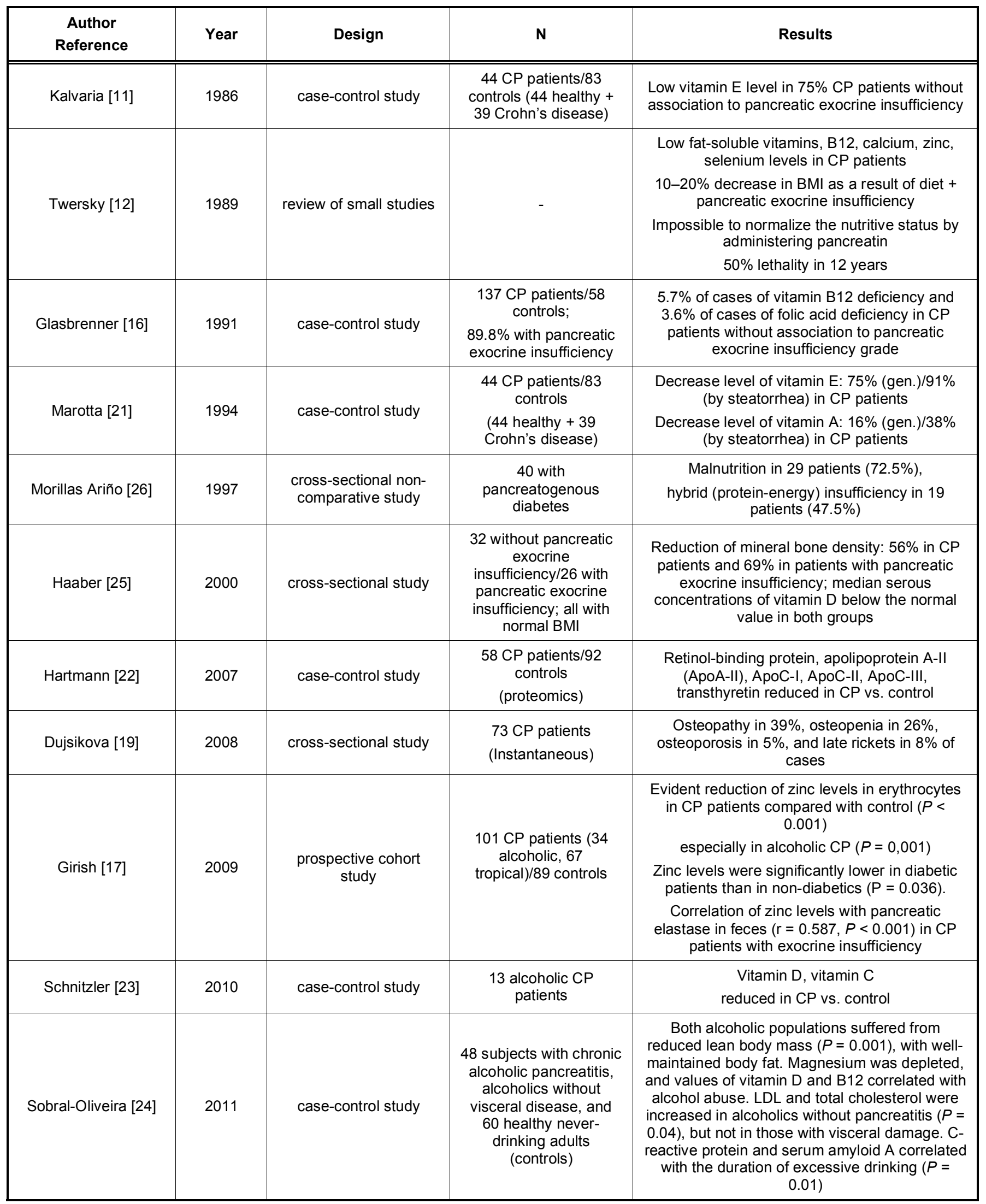


(Table 1). Continued.

\begin{tabular}{|c|c|c|c|c|}
\hline $\begin{array}{c}\text { Author } \\
\text { Reference }\end{array}$ & Year & Design & $\mathbf{N}$ & Results \\
\hline Lindkvist [20] & 2012 & retrospective study & $\begin{array}{l}114 \mathrm{CP} \text { patients, } \\
\text { including } 38 \text { with } \\
\text { pancreatic exocrine } \\
\text { insufficiency }\end{array}$ & $\begin{array}{c}\text { Low hemoglobin, albumin, prealbumin, retinol- } \\
\text { binding protein, magnesium levels in } \mathrm{CP} \\
\text { patients }\end{array}$ \\
\hline Kucheriavy̆̌luA [18] & 2012 & $\begin{array}{l}\text { retrospective, multi- } \\
\text { center study }\end{array}$ & 1637 CP patients & $\begin{array}{l}\text { Low hemoglobin, lymphocytes, albumin levels } \\
\text { and osteoporosis in CP patients; } \\
\text { Malnutrition discovered in } 45.9 \% \text { of CP patients }\end{array}$ \\
\hline Sikkens [14] & 2013 & cross-sectional study & $\begin{array}{l}40 \mathrm{CP} \text { patients, } \\
\text { including those with } \\
\text { pancreatic exocrine } \\
\text { insufficiency }\end{array}$ & $\begin{array}{c}\text { Deficiency of vitamin } \mathrm{A}, \mathrm{D}, \mathrm{E} \text {, and } \mathrm{K} \text { in } 3 \% \text {, } \\
53 \%, 10 \% \text {, and } 63 \% \text { of cases, respectively } \\
\text { Osteopenia and osteoporosis in } 45 \% \text { and } 10 \% \\
\text { of cases, respectively }\end{array}$ \\
\hline Duggan [15] & 2014 & $\begin{array}{l}\text { prospective cohort } \\
\text { study }\end{array}$ & $\begin{array}{l}128 \text { CP patients/66 } \\
\text { controls }\end{array}$ & $\begin{array}{c}\text { Deficiency of vitamins A and C in } 14.5 \% \text { and } \\
24.2 \% \text {, respectively }\end{array}$ \\
\hline
\end{tabular}

patients with severe malnutrition demonstrate a reduction of pancreatic enzymes in duodenal content, stool, and blood along with a decrease in total protein and albumin in the blood. Visualization methods reveal a substantial reduction of the pancreas in such patients, a tendency that is observed in all clinical types of trophological insufficiency and is more severe in the case of marasmus. Complex treatment of trophological insufficiency and correct and step-by-step nutritive correction restore pancreatic dimensions, which correlate with the volume of secretion and increase in BMI [44-46] but not with the primary form of insufficiency (marasmus, kwashiorkor, mixed form) [45].

The severity of malnutrition correlates with the level of hypotrophy of the pancreatic endocrine apparatus and insulin secretion levels. An adequate nutritive correction therapy can partially reverse the hypertrophy and restore higher insulin secretion levels; however, diabetes resulting from severe trophological insufficiency is not reversible [47].

The importance of malnutrition in the development of severe exocrine pancreatic insufficiency and fibrosis was demonstrated in early morphological studies. The canonical work reported by Volk B.W. and Lazarus S.S. (1960) [48] demonstrates the development of pancreatic acinar atrophy and the reduction of zymogenic granule quantities in rabbits fed a lowcalorie diet using optical microscopy. The same authors confirmed these results in 1964 using electron microscopy [49]. The next important milestone in the connection between malnutrition and pancreatic morphological alterations was the demonstration of pancreatic fibrosis. W.R. Blackburn and K. Vinijchaikul (1969) used electron microscopy to demonstrate pancreatic fibrosis in addition to atrophy in the kwashiorkor model of severe malnutrition [50]. Later studies demonstrated that atrophic and fibrotic alterations of the pancreatic parenchyma in kwashiorkor patients are combined with fat dystrophy in the pancreas and are highly expressed in the liver. Fibrosis was observed in all segments of the pancreas, but no severe fibrotic alterations were found. Fibrotic alterations in the pancreas were only observed in patients with marasmus and kwashiorkor-marasmus at a frequency of $32 \%$ and $29.2 \%$, respectively [51].

CP patients and patients with nutritive insufficiency may be at a higher risk for complications and a worse prognosis [52], but to date, no high-quality studies have confirmed these observations [53]. Data on nutritive insufficiency have been collected during the prolonged postoperative period from CP patients who needed surgery [30-32]. CP patients or patients suffering from nutritive insufficiency before their operation have a worse postoperative prognosis after pancreatoduo- 
denal resection or pancreatectomy [31,32]. This observation might be explained by the immunodeficiency that occurs in patients with $\mathrm{CP}$ and malnutrition [52]. A recent study reported a chance of 4.81 (95\% Cl 2.04-8.23) of developing complications (pseudocystis, parapancreatic exudate, and apostasis) in patients with a low BMI [18].

In summary, severe nutritive insufficiency can intensify the course of $\mathrm{CP}$ and the severity of exocrine and endocrine pancreatic insufficiencies. Early diagnosis of malnutrition and initiation of adequate substitutive enzyme therapy with nutritional support are key to the success of the treatment of CP patients.

\section{Nutritive Status Evaluation in CP Patients}

Nutritive status research in CP patients is based on a multidisciplinary method that includes the following procedures $[6,53]$ :

- Evaluation of the clinical presentation,

- Diagnosis of exocrine and endocrine pancreatic functions,

- Assessment of the body composition, bone tissue density, and biochemical and clinical blood counts,

- Definitions of food rations and lifestyle,

- Psychological evaluation focusing on the dependent symptoms of nutritive status and risk factors (nausea, anorexia, sitophobia, pain, alcohol addiction, and smoking).

Biochemical nutritive status markers should be evaluated 1-2 times per year and should include a fatsoluble vitamin and the microelement contents of the blood [6].

Although body mass and BMI are important parameters in estimating nutritive status, the food ration of $\mathrm{CP}$ patients cannot be based on these parameters alone. Fluid retention in a patient with hypoproteinemia and nutritive insufficiency is characterized by the absence of weight dynamics or even an increase of body mass and BMI (ascites, hypostasis). Therefore, an anthropometric examination that includes a bioimpedance analysis is recommended every 3-6 months. Protein deficiency in CP patients with a normal and relatively stable BMI could progress with a gradual decrease in muscle mass, resulting in muscle weakness, fatigue, and deterioration of the prognosis [30].

To evaluate the food ration, anthropometric parameters, including the volume of the upper arm muscles, thickness of the dermal-fat fold above the triceps, and lean body mass, must be used to evaluate the nutritive status, especially in patients with hypostases and ascites. Age and gender should also be considered [53].

Bioimpedance is an easy, reproducible, portable, non-invasive, and relatively cheap method to evaluate body composition and nutritive status. Bioimpedance analysis of healthy people and patients with various diseases reported in the ESPEN guidelines [54-56] demonstrates the possibility to evaluate the fat-free body mass, functioning somatic cell mass, and contents of the intracellular and extracellular liquid. Although the methodology of bioimpedance is objective in healthy people and patients with a stable hydroelectrolytic balance and is well correlated to age, gender, and ethnic affiliations, its clinical use for routine examination is not recommended in patients with a significant deviation from normal BMI or with hypostatic ascetic syndrome [6].

Whereas the function of skeletal muscles correlates with the total protein volume and body cell mass, a decrease in muscle mass will result in morphological alterations of the skeletal muscles and functional abnormalities [57]. Various studies have demonstrated a correlation between muscle power and the outcomes of acute and chronic diseases [57-59]. Patients with significant malnutrition and who are provided with intensive nutritional support regenerate muscle power initially; in contrast, the body composition regenerates slowly. Therefore, a long period of individualized nutritional support could stimulate the development of muscle mass and power and could further facilitate the gradual regeneration of nutritive status $[56,60]$.

Calculation of the power expenditure at rest could provide an estimation of the energy level needed to regenerate the mass and optimize the nutritional support to prevent complications; [61] however, this technology is not available in most clinics. Instead, the equations of Harris-Benedict (with parameters of height, body mass, gender, and age) are the most frequently used methods in the clinic [62].

With the high frequency of bone tissue pathology in $\mathrm{CP}$ patients, densitometry could be recommended 
annually; however, no studies have confirmed the need yet [6].

Micronutrient deficiency accentuates the severity of exocrine pancreatic insufficiency; diagnostic methods for pancreatic insufficiency can be developed by evaluating the micronutrient levels in the blood serum. Recent research by Lindkvist et al. [20] included 114 $\mathrm{CP}$ patients, and among various markers of nutritional deficiency, confirmed the specificity of several markers to exocrine pancreatic insufficiency using the 13Cinspiratory test with mixed triglycerides. These markers included hemoglobin, hematocrit, prothrombin time, lymphocytes, total protein, albumin, prealbumin, retinolbinding protein, cholesterol, triglycerides, amylase, folic acid, vitamin B12, glycohemoglobin $\mathrm{A} 1 \mathrm{C}$, transferrin, ferritin, magnesium, and zinc. Exocrine pancreatic insufficiency is also associated with lower values for magnesium, hemoglobin, albumin, prealbumin, and retinol-binding protein. A serum magnesium value of $<2.05 \mathrm{mg} / \mathrm{dl}$ is strongly associated with exocrine pancreatic insufficiency (OR 14.3; 95\% Cl 2.76-74.2) [63]. The new A.S.P.E.N. recommendations do not include serum albumin and prealbumin as main markers of nutritive insufficiency because they are more indicative of inflammation and are not associated with a decrease in weight, caloric limitation of the food ration, or the nitrogen balance [64].

\section{Nutritive Insufficiency Correction}

\section{Diet}

According to the program of nutritional risk screening (NRS 2002; [65]), detailing of current and usual food habits must be conducted by a dietician for patients at risk of nutritive insufficiency. Daily food rations are evaluated by means of a 24-hour food diary or by using a special software for food anamneses, which provide detailed information about the supply of energy, protein, fat, and micronutrients. A food frequency questionnaire can be used to investigate commonly consumed food products [66].

A rational diet and scheduled clinic appointments allow patients to reconcile the recommended and actual calorie and protein consumption [6]. A randomized study using this method with nutritive support showed an increase in body mass and BMI and a decrease in fecal fat excretion in patients with $\mathrm{CP}$ and nutritive insufficiency [67].

The first dietary recommendation is total alcohol abstinence. One should calculate the necessary 24- hour calorie ration. The calculation of resting energy expenditures, especially in patients with a low BMI $(<20$ $\mathrm{kg} / \mathrm{m} 2$ ), is necessary for an optimal 24-hour calculation of calories due to increased resting energy expenditures. A 24-hour calorie ration calculated as 35 $\mathrm{kkal} / \mathrm{kg} /$ day is considered capable of compensating for the increase in resting energy expenditures in approximately $80 \%$ of patients [4].

Frequent meals (4-8 times a day) with carbohydrate limitation are recommended, especially in the case of incretory pancreatic insufficiency $[4,6]$. A protein content of $1.0-1.5 \mathrm{~g} / \mathrm{kg} / \mathrm{day}$ is well tolerated by $\mathrm{CP}$ patients. A fat content of $30-40 \%$ in the calorie ration, especially of vegetable origin, is well tolerated.

In patients with a body mass deficiency and/or persistent steatorrhea, the addition to the food of medium chain triglycerides (MCT) may facilitate the absorption of fat $[4,6]$. MCTs in the unaltered form are absorbed in the small gut in the absence of lipase, colipase, and bile salts, and they subsequently reach the portal blood stream. MCTs could be used in theory, but they have a low energetic value and bad organoleptic qualities (e.g., bitter taste). The recommended amount of MCT consumption is $50 \mathrm{~g} /$ day; a higher dose could induce abnormal levels of ketone bodies and cause unwanted effects (fits, nausea, and diarrhea) [68]. Thus, MCTs must be used carefully by patients with $\mathrm{CP}$ and diabetes [4]. The following items are prescribed to patients with clinical or laboratory characteristics of micronutrient deficiency:

- $\quad$ Fat-soluble vitamins (A, D, E, and K) and/or

- $\quad$ Vitamin B12 and/or

- Other micronutrients (such as zinc, calcium, magnesium, and folic acid).

Traditionally, the diet recommended for CP patients consists of small amounts of dietary fiber because it may lead to enzyme absorption and increased malabsorption. Enzyme medication will compensate for the deficiency in fiber-sorbed enzymes [9,69-71] and aid in building a healthy nutritional status in CP patients. Adequate substitutive enzyme therapy provides weight stabilization in $10-15 \%$ of CP patients, making nutritive correction unnecessary $[72,73]$. The universal clinical markers for long-term follow-up CP patients are good health and an increase in body mass [6]. 


\section{Lifestyle Modification}

To minimize nutritive insufficiency risks and $\mathrm{CP}$ progression, it is necessary to avoid smoking and to estimate compliance (use of enzyme medication and dosing schedule maintenance) and pain control. Balanced physical activity is necessary to achieve optimal results in nutritive correction [57-59].

\section{Nutritive Correction}

Maldigestion of macronutrients is the main cause of progressive nutritional and metabolic abnormality in $\mathrm{CP}$ patients.

The indications for nutritive correction and the choice of method are defined by the maldigestion grade and existing diet status. The main purpose of nutritive correction is to guarantee a sufficient supply of macronutrients and micronutrients to reduce maldigestion, malabsorption, and other risk factors, ensuring preventive care or treatment of nutritive insufficiency. The treatment of exocrine pancreatic insufficiency begins with the diet recommendations and substitutive enzyme therapy with pancreatin medications. Approximately $80 \%$ of CP patients respond by stabilization of their nutritive status to standard complex therapy including analgesics, pancreatic enzymes, and modifications of food and lifestyle. On average, $10-15 \%$ of CP patients require nutritive correction, $5 \%$ need enteral feeding, and only $1 \%$ have indications for parenteral feeding $[3,72,74-76]$.

The efficacy of enteral feeding as a nutritive support for pancreatitis patients has been reported in many studies $[10,77,78]$. Enteral feeding stimulates not only the improvement of nutritive status rates but also reduces abdominal pain. The pain relief experienced during the administration of enteral feeding in CP patients can be explained by the probable reduction of cholecystokinin (CCK) levels in the serum. High values of CCK in blood serum could be responsible for pain persistence in CP patients [79]. In other words, CP patients with a meager food intake will have minimal postprandial stimulation of pancreatic secretory activity [80] and a lower CCK secretion.

\section{Antioxidants}

The efficacy of antioxidant vitamin/mineral complex administration to improve life quality and relieve pancreatic pain has been actively discussed in recent years [4].

The reduction of cysteine, cysteinylglycine, glutathione [81], tocopherol, vitamin A and carotenoids, and selenium [82] in $\mathrm{CP}$ patients suggests a connection between antioxidant deficiency and inflammation in pancreatic tissues. Free radicals and peroxidation products can destroy cell membranes or damage cells via oxidative stress [83]. Free radicals and peroxidation products cause the degranulation of mast cells with subsequent chemotaxis induction, inflammation, and pain [84]. Some studies have noted the presence of oxidative stress in patients with alcoholic and idiopathic CP [81,85-87]. One theory (2012) suggests that free radical accumulation in CP patients intensifies pancreatic injury and stimulates more intense pain [88].

The efficacy of antioxidants in reducing pancreatic pain in CP has been tested previously, but the results of different studies are inconsistent [89-95]. The first studies evaluated the effect of mono-medications with antioxidant activity of allopurinol [91,94], dimethylsulphoxide (DMSO) [91], ademeteonin [93], and curcumin [95] (the active curcuma component). Many studies $[89,90,92,96,97]$ have demonstrated an effect of pain relief with antioxidant complexes that include selenium, $\beta$-carotene, vitamin $\mathrm{C}$, vitamin $\mathrm{E}$, and methionine.

Kirk et al. [89] published a randomized study including 36 patients with potential CP who received either the antioxidant complex (selenium $75 \mathrm{mcg}, \beta-$ carotene $3 \mathrm{mg}$, tocopherol $25 \mathrm{mg}$, cevitamic acid 150 $\mathrm{mg}$, and methionine $400 \mathrm{mg}$ ) or placebo over 10 weeks. Patients with $\mathrm{CP}$ who received the antioxidant complex experienced a significant improvement in quality of life, pain, and physical and social functioning [89]. The largest randomized trial included 127 patients and was conducted by Bhardwaj et al [96]. Patients received antioxidant complexes containing selenium $600 \mathrm{mcg}$, cevitamic acid $540 \mathrm{mg}, 9000 \mathrm{ME} \beta$-carotene, $270 \mathrm{ME} \alpha$-tocopherol, and $2000 \mathrm{mg}$ methionine or placebo. The number of days without pain was significantly increased in the treatment group $(7.4 \pm 6.8$ days without pain [placebo] over a month vs. $3.2 \pm 4.0$ days without pain [treatment] over a month; $P<0,001$ ), diminishing the need for analgesics and decreasing the hospitalization risk compared with placebo [96]. Another recent placebo-controlled trial included $61 \mathrm{CP}$ patients who received either placebo or an antioxidant complex for 3 months [63]. The authors noted not only a reduction in pancreatic pain (17/31 in the treatment group vs. $9 / 30$ in the placebo group; $p=0.05$ ) but also an antifibrotic effect assessed by TGF- $\beta 1$ levels in the blood serum $(p=0.001)$ [63].

The most recent randomized controlled trial conducted in Manchester compared the efficacy of 
antioxidant therapy to placebo in $70 \mathrm{CP}$ patients (A.K. Siriwardena et al, ANTICIPATE study, 2012). The results did not show any substantial pain reduction or life of quality improvement [98]; this publication was highly criticized in several articles $[99,100]$.

The study by Siriwardena et al. [98] influenced the results of the meta-analysis estimating the pain relief efficacy of antioxidants in CP patients [101]. This metaanalysis included 9 randomized trials $(\mathrm{n}=390)$ and demonstrated that higher antioxidant levels in the blood $(P<0.00001)$ did not affect pain $(P=0,67)$ and led to an increase in adverse effects $(P<0,01)$ [101]. An earlier meta-analysis by Bjelakovic et al. [102] demonstrated an increase in lethality in patients taking the antioxidant complex over a mean period of 2.7 years for primary or secondary preventive treatment of heart diseases, cancer, and infectious diseases.

In summary, there might be a potential benefit of antioxidants in CP patients if the purpose is pain relief, a reduction of inflammation, and potentially antifibrotic activity. The contradictory results of the trials might be due to differences in research designs, variable antioxidant treatment durations, and the variable medications tested (monocomponent and various polycomponent complexes).

\section{CONCLUSIONS}

Deviations in nutritive status play an important role in the pathophysiology of $\mathrm{CP}$ and in the prognosis of this disease. The limitation of food ration without nutritional support not only results in caloric and essential nutrient insufficiency but also intensifies the primary pancreatic insufficiency.

Future research is needed that takes into account the various nutritive risks that would help the development of case management algorithms for patients with CP. Particular attention must be paid to body composition, nutrient absorption, metabolism, and micronutrient deficiency evaluation. To include nutritive correction in routine practice, controlled trials must be conducted with relevant clinical CP endpoints such as disease incidences, quality of life, physical functioning, and survival.

\section{ACKNOWLEDGMENTS}

The authors would like to thank NPG Language Editing for the English language editing and review.

\section{FINANCIAL DISCLOSURES}

The authors have nothing to disclose.

\section{CONFLICTS OF INTEREST}

None of the authors has a commercial association (i.e., consultancies, stock ownership, equity interest, patent/licensing arrangements, etc.) that might pose a conflict of interest in connection with the submitted manuscript.

\section{SUPPORTIVE FOUNDATIONS}

None.

\section{AUTHOR CONTRIBUTIONS}

The authors contributed equally to the conception of the review and drafting of the manuscript

\section{REFERENCES}

[1] Clain JE, Pearson RK. Diagnosis of chronic pancreatitis: is a gold standard necessary? Surg Clin NorthAm 1999; 79: 829845.

http://dx.doi.org/10.1016/S0039-6109(05)70046-3

[2] Yadav D, Lowenfels AB. The epidemiology of pancreatitis and pancreatic cancer. Gastroenterology 2013; 144: 12521261.

http://dx.doi.org/10.1053/j.gastro.2013.01.068

[3] Maev IV, Kucheriawyı̆ luA. Modern approaches to diagnostics and treatment of chronic pancreatitis. Klin Med (Mosk) 2013; 91: 10-16.

[4] Afghani E, Sinha A, Singh VK. An overview of the diagnosis and management of nutrition in chronic pancreatitis. Nutr Clin Pract 2014; 29: 295-311. http://dx.doi.org/10.1177/0884533614529996

[5] Pezzilli R, Morselli Labate AM, Ceciliato R, et al. Quality of life in patients with chronic pancreatitis. Dig Liver Dis 2005; 37: 181-189. http://dx.doi.org/10.1016/j.dld.2004.10.007

[6] Rasmussen $\mathrm{HH}$, Irtun O, Olesen SS, Drewes AM, Holst M. Nutrition in chronic pancreatitis. World J Gastroenterol 2013; 19: 7267-7275.

http://dx.doi.org/ 10.3748/wjg.v19.i42.7267

[7] Gachago C, Draganov PV. Pain management in chronic pancreatitis. World J Gastroenterol 2008; 14: 3137-3148. http://dx.doi.org/10.3748/wjg.14.3137

[8] Giger U, Stanga Z, DeLegge MH. Management of chronic pancreatitis. Nutr Clin Pract 2004; 19: 37-49. http://dx.doi.org/10.1177/011542650401900137

[9] Sikkens EC, Cahen DL, van Eijck C, Kuipers EJ, Bruno MJ Patients with exocrine insufficiency due to chronic pancreatitis are undertreated: a Dutch national survey. Pancreatology 2012; 12: 71-73. http://dx.doi.org/10.1016/j.pan.2011.12.010

[10] Skipworth JR, Raptis DA, Wijesuriya S, et al. The use of nasojejunal nutrition in patients with chronic pancreatitis. JOP 2011; 12 : 574-580.

[11] Kalvaria I, Labadarios D, Shephard GS, Visser L, Marks IN Biochemical vitamin $E$ deficiency in chronic pancreatitis. Int $J$ Pancreatol 1986; 1: 119-128. 
[12] Twersky Y, Bank S. Nutritional deficiencies in chronic pancreatitis. Gastroenterol Clin North Am 1989; 18: 543-565.

[13] Bang UC, Benfield T, Bendtsen F, Hyldstrup L, Beck Jensen JE. The risk of fractures among patients with cirrhosis or chronic pancreatitis. Clin Gastroenterol Hepatol 2014; 12: 320-326.

http://dx.doi.org/10.1016/j.cgh.2013.04.031

[14] Sikkens EC, Cahen DL, Koch AD, et al. The prevalence of fat-soluble vitamin deficiencies and a decreased bone mass in patients with chronic pancreatitis. Pancreatology 2013; 13: 238-242.

http://dx.doi.org/10.1016/j.pan.2013.02.008

[15] Duggan SN, Smyth ND, O'Sullivan M, Feehan S, Ridgway $\mathrm{PF}$, Conlon KC. The prevalence of malnutrition and fatsoluble vitamin deficiencies in chronic pancreatitis. Nutr Clin Pract 2014; 29: 348-354.

http://dx.doi.org/10.1177/0884533614528361

[16] Glasbrenner B, Malfertheiner $P$, Büchler $M$, Kuhn K, Ditschuneit H. Vitamin B12 and folic acid deficiency in chronic pancreatitis: a relevant disorder? Klin Wochenschr 1991; 69: 168-172.

http://dx.doi.org/10.1007/BF01665861

[17] Girish BN, Rajesh G, Vaidyanathan K, Balakrishnan V. Zinc status in chronic pancreatitis and its relationship with exocrine and endocrine insufficiency. JOP 2009; 10: 651656.

[18] Kucheriavyı̌ luA, Moskaleva AB, Sviridova AV, et al. Nutritional status as a risk factor of chronic pancreatitis complications and pancreatic insufficiency development. Eksp Klin Gastroenterol 2012; 7: 10-16.

[19] Dujsikova H, Dite P, Tomandl J, Sevcikova A, Precechtelova M. Occurrence of metabolic osteopathy in patients with chronic pancreatitis. Pancreatology 2008; 8: 583-586.

http://dx.doi.org/10.1159/000159845

[20] Lindkvist $B$, Dominguez-Munoz JE, Luaces-Regueira $M$, Castineiras-Alvarino M, Nieto-Garcia L, Iglesias-Garcia J. Serum nutritional markers for prediction of pancreatic exocrine insufficiency in chronic pancreatitis. Pancreatology 2012; 12: 305-310.

http://dx.doi.org/10.1016/j.pan.2012.04.006

[21] Marotta F, Labadarios D, Frazer L, Girdwood A, Marks IN. Fat-soluble vitamin concentration in chronic alcohol-induced pancreatitis. Relationship with steatorrhea. Dig Dis Sci 1994; 39: 993-998. http://dx.doi.org/10.1007/BF02087550

[22] Hartmann D, Felix K, Ehmann M, et al. Protein expression profiling reveals distinctive changes in serum proteins associated with chronic pancreatitis. Pancreas 2007; 35: 334-342.

http://dx.doi.org/10.1097/mpa.0b013e3180cac723

[23] Schnitzler CM, Mesquita JM, Shires RJ. Cortical and trabecular bone microarchitecture and turnover in alcoholinduced chronic pancreatitis: a histomorphometric study. Bone Miner Metab 2010; 28: 456-467.

http://dx.doi.org/10.1007/s00774-009-0151-x

[24] Sobral-Oliveira MB, Faintuch J, Guarita DR, Oliveira CP, Carrilho FJ. Nutritional profile of asymptomatic alcoholic patients. Arq Gastroenterol 2011; 48: 112-11. http://dx.doi.org/10.1590/S0004-28032011000200006

[25] Haaber AB, Rosenfalck AM, Hansen B, Hilsted J, Larsen S. Bone mineral metabolism, bone mineral density, and body composition in patients with chronic pancreatitis and pancreatic exocrine insufficiency. Int J Pancreatol 2000; 27: 21-27. http://dx.doi.org/10.1385/IJGC:27:1:21

[26] Morillas Ariño C, Hernández Mijares A, Morillas Ariño MJ, et al. Nutritional status assessment in diabetes mellitus secondary to chronic alcoholic pancreatitis. Med Clin (Barc) 1997; 108: 373-376.
[27] Domínguez-Muñoz JE, Iglesias-García J, Vilariño-Insua M, Iglesias-Rey M. 13C-mixed triglyceride breath test to assess oral enzyme substitution therapy in patients with chronic pancreatitis. Clin Gastroenterol Hepatol 2007; 5: 484-488. http://dx.doi.org/10.1016/j.cgh.2007.01.004

[28] Affronti J. Chronic pancreatitis and exocrine insufficiency. Prim Care 2011; 38: 515-537. http://dx.doi.org/10.1016/j.pop.2011.05.007

[29] Armbrecht U. Chronic pancreatitis: weight loss and poor physical performance - experience from a specialized rehabilitation centre. Rehabilitation (Stuttg) 2001; 40: 332336. http://dx.doi.org/10.1055/s-2001-18966

[30] Riediger $\mathrm{H}$, Adam U, Fischer E, et al. Long-term outcome after resection for chronic pancreatitis in 224 patients. $J$ Gastrointest Surg 2007; 11: 949-959; discussion 959-960. http://dx.doi.org/10.1007/s11605-007-0155-6

[31] Park JW, Jang JY, Kim EJ, et al. Effects of pancreatectomy on nutritional state, pancreatic function and quality of life. $\mathrm{Br}$ J Surg 2013; 100: 1064-1070. http://dx.doi.org/10.1002/bjs.9146

[32] Ahmad SA, Edwards MJ, Sutton JM, et al. Factors influencing readmission after pancreaticoduodenectomy: a multi-institutional study of 1302 patients. Ann Surg 2012; 256: 529-37. http://dx.doi.org/10.1097/SLA.0b013e318265ef0b

[33] Petersen JM, Forsmark CE. Chronic pancreatitis and maldigestion. Semin Gastrointest Dis 2002; 13: 191-199.

[34] Havala T, Shronts E, Cerra F. Nutritional support in acute pancreatitis. Gastroenterol Clin North Am 1989; 18: 525-542.

[35] Di Carlo V, Nespoli A, Chiesa R, et al. Hemodynamic and metabolic impairment in acute pancreatitis. World J Surg 1981; 5: 329-339. http://dx.doi.org/10.1007/BF01657989

[36] Shaw JH, Wolfe RR. Glucose, fatty acid, and urea kinetics in patients with severe pancreatitis. The response to substrate infusion and total parenteral nutrition. Ann Surg 1986; 204 665-672.

http://dx.doi.org/10.1097/00000658-198612000-00008

[37] Hébuterne X, Hastier P, Péroux JL, Zeboudj N, Delmont JP, Rampal P. Resting energy expenditure in patients with alcoholic chronic pancreatitis. Dig Dis Sci 1996; 41: 533-539. http://dx.doi.org/10.1007/BF02282334

[38] Dickerson RN, Vehe KL, Mullen JL, Feurer ID. Resting energy expenditure in patients with pancreatitis. Crit Care Med 1991; 19: 484-490. http://dx.doi.org/10.1097/00003246-199104000-00005

[39] Sitzmann JV, Steinborn PA, Zinner MJ, Cameron JL. Total parenteral nutrition and alternate energy substrates in treatment of severe acute pancreatitis. Surg Gynecol Obstet 1989; 168: 311-317.

[40] Marulendra S, Kirby DF. Nutrition support in pancreatitis. Nutr Clin Pract 1995; 10: 45-53. http://dx.doi.org/10.1177/011542659501000245

[41] Chowdhury RS, Forsmark CE, Davis RH, Toskes PP, Verne GN. Prevalence of gastroparesis in patients with small duct chronic pancreatitis. Pancreas 2003; 26: 235-238. http://dx.doi.org/10.1097/00006676-200304000-00005

[42] Davies AR, Froomes PR, French CJ, et al. Randomized comparison of nasojejunal and nasogastric feeding in critically ill patients. Crit Care Med 2002; 30: 586-90. http://dx.doi.org/10.1097/00003246-200203000-00016

[43] DiMagno EP, Go VL, Summerskill WH. Relations between pancreatic enzyme ouputs and malabsorption in severe pancreatic insufficiency. N Engl J Med 1973; 288: 813-815. http://dx.doi.org/10.1056/NEJM197304192881603 
[44] Cuntz U, Frank G, Lehnert P, Fichter M. Interrelationships between the size of the pancreas and the weight of patients with eating disorders. Int J Eat Disord 2000; 27: 297-303. http://dx.doi.org/10.1002/(SICI)1098108X(200004)27:3<297::AID-EAT6>3.0.CO;2-6

[45] El-Hodhod MA, Nassar MF, Hetta OA, Gomaa SM. Pancreatic size in protein energy malnutrition: a predictor of nutritional recovery. Eur J Clin Nutr 2005; 59: 467-473. http://dx.doi.org/10.1038/sj.ejcn.1602053

[46] Sauniere JF, Sarles H. Exocrine pancreatic function and protein-calorie malnutrition in Dakar and Abidjan (West Africa): silent pancreatic insufficiency. Am J Clin Nutr 1988; 48: 1233-1238.

[47] Swenne I, Borg LA, Crace CJ, Schnell Landström A. Persistent reduction of pancreatic beta-cell mass after a limited period of protein-energy malnutrition in the young rat. Diabetologia 1992; 35: 939-945.

http://dx.doi.org/10.1007/BF00401422

[48] Volk BW, Lazarus SS. Rabbit Pancreas in Protein Malnutrition (Experimental Kwashiorkor) and after Cortisone Administration. Am J Pathol 1960; 37: 121-135.

[49] Lazarus SS, Volk BW. Electron microscopy and histochemistry of rabbit pancreas in protein malnutrition (Experimental kwashiorkor). Am J Pathol 1964; 44: 95-111.

[50] Blackburn WR, Vinijchaikul K. The pancreas in kwashiorkor. An electron microscopic study. Lab Invest 1969; 20: 305-18.

[51] Brooks SE, Golden MH. The exocrine pancreas in kwashiorkor and marasmus. Light and electron microscopy. West Indian Med J 1992; 41: 56-60.

[52] Schnelldorfer T, Adams DB. The effect of malnutrition on morbidity after surgery for chronic pancreatitis. Am Surg 2005; 71: 466-472; discussion 472-473.

[53] Duggan S, O'Sullivan M, Feehan S, Ridgway P, Conlon K. Nutrition treatment of deficiency and malnutrition in chronic pancreatitis: a review. Nutr Clin Pract 2010; 25: 362-370. http://dx.doi.org/10.1177/0884533610373772

[54] Kyle UG, Bosaeus I, De Lorenzo AD, et al. Bioelectrical impedance analysis-part I: review of principles and methods. Clin Nutr 2004; 23: 1226-1243.

http://dx.doi.org/10.1016/j.clnu.2004.06.004

[55] Kyle UG, Bosaeus I, De Lorenzo AD, et al. Bioelectrical impedance analysis-part II: utilization in clinical practice. Clin Nutr 2004; 23: 1430-1453. http://dx.doi.org/10.1016/j.clnu.2004.09.012

[56] Norman K, Pirlich M, Sorensen J, et al. Bioimpedance vector analysis as a measure of muscle function. Clin Nutr 2009; 28: 78-82.

http://dx.doi.org/10.1016/j.clnu.2008.11.001

[57] Tieland M, Dirks ML, van der Zwaluw N, et al. Protein supplementation increases muscle mass gain during prolonged resistance-type exercise training in frail elderly people: a randomized, double-blind, placebo-controlled trial. J Am Med Dir Assoc 2012; 13: 713-719.

http://dx.doi.org/10.1016/j.jamda.2012.05.020

[58] Candow DG, Forbes SC, Little JP, Cornish SM, Pinkoski C, Chilibeck PD. Effect of nutritional interventions and resistance exercise on aging muscle mass and strength. Biogerontology 2012; 13: 345-358. http://dx.doi.org/10.1007/s10522-012-9385-4

[59] Geirsdottir OG, Arnarson A, Briem K, Ramel A, Jonsson PV, Thorsdottir I. Effect of 12-week resistance exercise program on body composition, muscle strength, physical function, and glucose metabolism in healthy, insulin-resistant, and diabetic elderly Icelanders. J Gerontol A Biol Sci Med Sci 2012; 67: 1259-1265.

http://dx.doi.org/10.1093/gerona/gls096

[60] Norman K, Stobäus N, Gonzalez MC, Schulzke JD, Pirlich M. Hand grip strength: outcome predictor and marker of nutritional status. Clin Nutr 2011; 30: 135-142. http://dx.doi.org/10.1016/j.clnu.2010.09.010
[61] Słodkowski M, Rubinsztajn R, Cebulski W, Krasnodebski IW. A case report of severe hypophosphatemia in the course of refeeding syndrome. Pol Merkur Lekarski 2004; 17: 638-639.

[62] Harris JA, Benedict FG. A Biometric Study of Human Basal Metabolism. Proc Natl Acad Sci USA 1918; 4: 370-373. http://dx.doi.org/10.1073/pnas.4.12.370

[63] Dhingra R, Singh N, Sachdev V, Upadhyay AD, Saraya A Effect of antioxidant supplementation on surrogate markers of fibrosis in chronic pancreatitis: a randomized, placebocontrolled trial. Pancreas 2013; 42: 589-595. http://dx.doi.org/10.1097/MPA.0b013e31826dc2d7

[64] White JV, Guenter P, Jensen G, Malone A, Schofield M; Academy of Nutrition and Dietetics Malnutrition Work Group; A.S.P.E.N. Malnutrition Task Force; A.S.P.E.N. Consensus statement of the academy of nutrition and Dietetics/American society for parenteral and enteral nutrition: characteristics recommended for the identification and documentation of adult malnutrition (undernutrition). J Acad Nutr Diet 2012; 112: $730-738$ http://dx.doi.org/10.1016/j.jand.2012.03.012

[65] Kondrup J, Rasmussen $\mathrm{HH}$, Hamberg O, Stanga Z Nutritional risk screening (NRS 2002): a new method based on an analysis of controlled clinical trials. Clin Nutr 2003; 22: 321-336.

http://dx.doi.org/10.1016/S0261-5614(02)00214-5

[66] Streppel MT, de Vries JH, Meijboom S, et al. Relative validity of the food frequency questionnaire used to assess dietary intake in the Leiden Longevity Study. Nutr J 2013; 12: 75. http://dx.doi.org/10.1186/1475-2891-12-75

[67] Singh S, Midha S, Singh N, Joshi YK, Garg PK. Dietary counseling versus dietary supplements for malnutrition in chronic pancreatitis: a randomized controlled trial. Clin Gastroenterol Hepatol 2008; 6: 353-359. http://dx.doi.org/10.1016/j.cgh.2007.12.040

[68] Yeh YY, Zee P. Relation of ketosis to metabolic changes induced by acute medium-chain triglyceride feeding in rats. $\mathrm{J}$ Nutr 1976; 106: 58-67.

[69] Nakajima K, Oshida H, Muneyuki T, Kakei M. Pancrelipase: an evidence-based review of its use for treating pancreatic exocrine insufficiency. Core Evid 2012; 7: 77-91. http://dx.doi.org/10.2147/CE.S26705

[70] Domínguez-Muñoz JE. Chronic pancreatitis and persistent steatorrhea: what is the correct dose of enzymes? Clin Gastroenterol Hepatol 2011; 9: 541-546.

http://dx.doi.org/10.1016/j.cgh.2011.02.027

[71] Domínguez-Muñoz JE, Iglesias-García J. Oral pancreatic enzyme substitution therapy in chronic pancreatitis: is clinical response an appropriate marker for evaluation of therapeutic efficacy? JOP 2010; 11: 158-162.

[72] Plauth M, Cabré E, Campillo B, et al. ESPEN Guidelines on Parenteral Nutrition: hepatology. Clin Nutr 2009; 28: 436444.

http://dx.doi.org/10.1016/j.clnu.2009.04.019

[73] Lochs H, Dejong C, Hammarqvist F, et al. ESPEN Guidelines on Enteral Nutrition: Gastroenterology. Clin Nutr 2006; 25 260-274.

http://dx.doi.org/10.1016/i.clnu.2006.01.007

[74] Meier RF, Beglinger C. Nutrition in pancreatic diseases. Best Pract Res Clin Gastroenterol 2006; 20: 507-529. http://dx.doi.org/10.1016/j.bpg.2006.01.004

[75] Meier R, Ockenga J, Pertkiewicz M, et al. ESPEN Guidelines on Enteral Nutrition: Pancreas. Clin Nutr 2006; 25: 275-284 http://dx.doi.org/10.1016/j.clnu.2006.01.019

[76] Gianotti L, Meier R, Lobo DN, et al. ESPEN guidelines on parenteral nutrition: pancreas. Clin Nutr. 2009; 28: 428-435. http://dx.doi.org/10.1016/j.clnu.2009.04.003

[77] Stanga Z, Giger U, Marx A, DeLegge MH. Effect of jejunal long-term feeding in chronic pancreatitis. JPEN J Parenter Enteral Nutr 2005; 29: 12-20.

http://dx.doi.org/10.1177/014860710502900112 
[78] Hamvas J, Schwab R, Pap A. Jejunal feeding in chronic pancreatitis with severe necrosis. JOP. J Pancreas (Online) 2001; 2: 112-116.

[79] Toskes PP. Update on diagnosis and management of chronic pancreatitis. Curr Gastroenterol Rep 1999; 1: 145153.

http://dx.doi.org/10.1007/s11894-996-0014-8

[80] Corcoy R, Sanchez JM, Domingo P, Net A. Nutrition in the patient with severe acute pancreatitis. Nutrition 1988; 4: 26975.

[81] Verlaan M, Roelofs HM, van-Schaik A, et al. Assessment of oxidative stress in chronic pancreatitis patients. World $\mathrm{J}$ Gastroenterol 2006; 12: 5705-5710.

[82] Morris-Stiff GJ, Bowrey DJ, Oleesky D, Davies M, Clark GW, Puntis MC. The antioxidant profiles of patients with recurrent acute and chronic pancreatitis. Am J Gastroenterol 1999; 94: 2135-2140.

http://dx.doi.org/10.1111/j.1572-0241.1999.01311.x

[83] Valko M, Leibfritz D, Moncol J, Cronin MT, Mazur M, Telser $\mathrm{J}$. Free radicals and antioxidants in normal physiological functions and human disease. Int J Biochem Cell Biol 2007; 39: 44-84.

http://dx.doi.org/10.1016/j.biocel.2006.07.001

[84] McCloy R. Chronic pancreatitis at Manchester, UK. Focus on antioxidant therapy. Digestion 1998; 59 Suppl 4: 36-48. http://dx.doi.org/10.1159/000051441

[85] Braganza JM, Schofield D, Snehalatha C, Mohan V. Micronutrient antioxidant status in tropical compared with temperatezone chronic pancreatitis. Scand J Gastroenterol 1993; 28: 1098-1104. http://dx.doi.org/10.3109/00365529309098316

[86] Szuster-Ciesielska A, Daniluk J, Kandefer-Szerszen M. Oxidative stress in blood of patients with alcohol-related pancreatitis. Pancreas 2001; 22: 261-266. http://dx.doi.org/10.1097/00006676-200104000-00006

[87] Kodydkova J, Vavrova L, Stankova B, et al. Antioxidant status and oxidative stress markers in pancreatic cancer and chronic pancreatitis. Pancreas 2013; 42: 614-621. http://dx.doi.org/10.1097/MPA.0b013e318288360a

[88] Grigsby B, Rodriguez-Rilo H, Khan K. Antioxidants and chronic pancreatitis: theory of oxidative stress and trials of antioxidant therapy. Dig Dis Sci 2012; 57: 835-841. http://dx.doi.org/10.1007/s10620-012-2037-3

[89] Kirk GR, White JS, McKie L, et al. Combined antioxidant therapy reduces pain and improves quality of life in chronic pancreatitis. J Gastrointest Surg 2006; 10: 499-503. http://dx.doi.org/10.1016/j.gassur.2005.08.035

[90] Uden S, Bilton D, Nathan L, Hunt LP, Main C, Braganza JM. Antioxidant therapy for recurrent pancreatitis: Placebocontrolled trial. Aliment Pharmacol Ther 1990; 4: 357-371.

http://dx.doi.org/10.1111/j.1365-2036.1990.tb00482.x
[91] Salim AS. Role of oxygen-derived free radical scavengers in the treatment of recurrent pain produced by chronic pancreatitis. A new approach. Arch Surg 1991; 126: 11091114.

http://dx.doi.org/10.1001/archsurg.1991.01410330067010

[92] Uden S, Schofield D, Miller PF, Day JP, Bottiglier T, Braganza JM. Antioxidant therapy for recurrent pancreatitis: Biochemical profiles in a placebo-controlled trial. Aliment Pharmacol Ther 1992; 6: 229-240. http://dx.doi.org/10.1111/j.1365-2036.1992.tb00266.x

[93] Bilton D, Schofield D, Mei G, Kay PM, Bottiglieri T, Braganza JM. Placebo-controlled trials of antioxidant therapy including S-adenosulmethionine in patients with recurrent nongallstone pancreatitis. Drug Invest 1994; 8: 10-20. http://dx.doi.org/10.1007/BF03257422

[94] Banks PA, Hughes $M$, Ferrante $M$, Noordhoek EC Ramagopal V, Slivka A. Does allopurinol reduce pain of chronic pancreatitis? Int J Pancreatol 1997; 22: 171-176.

[95] Durgaprasad S, Pai CG, Vasanthkumar, Alvres JF, Namitha S. A pilot study of the antioxidant effect of curcumin in tropical pancreatitis. Indian J Med Res 2005; 122: 315-318.

[96] Bhardwaj P, Garg PK, Maulik SK, Saraya A, Tandon RK Acharya SK. A randomized controlled trial of antioxidant supplementation for pain relief in patients with chronic pancreatitis. Gastroenterology 2009; 136: 149-159.e2. http://dx.doi.org/10.1053/j.gastro.2008.09.028

[97] Shah NS, Makin AJ, Sheen AJ, Siriwardena AK. Quality of life assessment in patients with chronic pancreatitis receiving antioxidant therapy. World J Gastroenterol 2010; 16: 40664071.

http://dx.doi.org/10.3748/wjg.v16.i32.4066

[98] Siriwardena AK, Mason JM, Sheen AJ, Makin AJ, Shah NS Antioxidant therapy does not reduce pain in patients with chronic pancreatitis: the ANTICIPATE study. Gastroenterology 2012; 143: 655-663.

http://dx.doi.org/10.1053/i.gastro.2012.05.046

[99] Braganza JM. Micronutrient therapy for chronic pancreatitis: premises and pitfalls. JOP 2013; 14: 304-308.

http://dx.doi.org/10.6092/1590-8577/1580

[100] Talukdar R, Reddy DN. Pain in chronic pancreatitis: managing beyond the pancreatic duct. World J Gastroenterol 2013; 19: 6319-6328.

http://dx.doi.org/10.3748/wjg.v19.i38.6319

[101] Cai GH, Huang J, Zhao Y, Chen J, Wu HH, Dong YL, Smith HS, Li YQ, Wang W, Wu SX. Antioxidant therapy for pain relief in patients with chronic pancreatitis: systematic review and meta-analysis. Pain Physician 2013; 16: 521-532.

[102] Bjelakovic G, Nikolova D, Gluud LL, Simonetti RG, Gluud C. Mortality in randomized trials of antioxidant supplements for primary and secondary prevention: systematic review and meta-analysis. JAMA 2007; 297: 842-857. http://dx.doi.org/10.1001/iama.297.8.842

(c) 2014 Kucheryavyy and Andreev; Licensee Lifescience Global.

This is an open access article licensed under the terms of the Creative Commons Attribution Non-Commercial License (http://creativecommons.org/licenses/by-nc/3.0/) which permits unrestricted, non-commercial use, distribution and reproduction in any medium, provided the work is properly cited. 